\title{
Perceived Harm and Addictiveness of E-Cigarette: A Systematic Review
}

\author{
Susi Ari Kristina ${ }^{1 *}$, Ni Putu Ayu Linda Permitasari ${ }^{2}$, Ahmad Intihan $^{3}$, Dima Nurrohmah Hayati ${ }^{3}$, Kharisma \\ Aprilita Rosyidah ${ }^{3}$ \\ 1. Department of Pharmaceutics, Faculty of Pharmacy, Universitas Gadjah Mada \\ 2. Research Assistant, Faculty of Pharmacy, Universitas Gadjah Mada \\ 3. Master Student in Pharmacy Management, Faculty of Pharmacy, Universitas Gadjah Mada \\ Submitted: 25-02-2019 Revised:05-04-2019 Accepted: 20-06-2019 \\ Korespondensi : Susi Ari Kristina : Email : susiari_k@ugm.ac.id
}

\begin{abstract}
The popularity of electronic nicotine delivery systems (ENDS), also known as e-cigarette, has been growing rapidly in the past years. Therefore, it is also important to explore how e-cigarette users perceive its harm and addiction risk. The aim of this study is to review and determine perceived harm and addictiveness of e-cigarette among e-cigarette users. We conducted a systematic review for published articles in English that had reported about perceived harm and addictiveness of e-cigarette published during year 2008 to 2018. Relevant studies were located through an extensive search from three electronic databases (PubMed, Science Direct, and Cochrane Database of Systematic Reviews) and Google Scholar on October 2018. Key terms used were "perceived harm", "perceived risk", "harm and addictiveness", "belief", "electronic cigarette", "e-cigarette", and "vaping". A result of 88 studies were retrieved and reviewed. After further inspection of references from the collected studies, only 5 selected studies met all inclusion criteria. The final studies consisted of three cross-sectional studies, one longitudinal, and one prospective study. E-cigarette were perceived harmless and less addictive than cigarettes among its users with many predictors associated, including sex, age, race, education, advertisement and health belief for smoking cessation. Compared to non-users, e-cigarette users were significantly less likely to worry about the health risks, either its harm or addictiveness. E-cigarette was perceived harmless and less addictive than tobacco cigarettes. Further study about e-cigarette profile is particularly important to design public health messages that accurately interpret the scientific data on the potential harm and addictiveness of e-cigarette.
\end{abstract}

Keywords: ENDS, e-cigarette, harm, addictiveness.

\section{INTRODUCTION}

The use of electronic nicotine delivery systems (ENDS), also known as vape pens, vaping devices or e-cigarette, is increasing rapidly in some countries ${ }^{1,2}$. E-cigarette use among adolescents has increased over the years and has surpassed conventional cigarette smoking 3,4 . E-cigarette also have been advertised as smoking cessation tools in some countries. In public health sector, the longterm effects of e-cigarette use to control smoking have generated both debate and concern due to lack of safety and efficacy data $^{5,6}$. However, awareness and perceived harm of e-cigarette did not show evidence of promoting smoking cessation at the population level ${ }^{7,8}$. The tobacco control community is fiercely divided on issues about e-cigarette safety and efficacy for smoking cessation whether e-cigarette promote youth uptake of cigarette smoking and the regulation ${ }^{9}$.

One of significant concerns of ecigarette use is addiction. E-cigarette liquid typically contains nicotine, an addictive substance naturally found in tobacco ${ }^{10,11}$. Other health effect of e-cigarette are also become part of the concern although the long-term health effects of e-cigarette use are largely unknown. Several studies suggest e-cigarette use may cause respiratory harm, increased blood pressure, and can interfere with adolescent brain development. Chemicals found in ecigarette aerosol can deposit particles such as nickel, tin, and chromium into the lungs, causing local respiratory toxicity ${ }^{12}$.

To date, studies indicate that the majority of e-cigarette users are current or 
Table I. Inclusion and Exclusion Criteria for The Reviewed Articles

\begin{tabular}{lll}
\hline \multicolumn{1}{c}{ Inclusion Criteria } & \multicolumn{1}{c}{ Exclusion Criteria } \\
\hline 1. Published in the English language & 1. & Review articles, letters and comments \\
2. Time frame year from $2008-2018$ & 2. Article was not based on original research \\
3. Report both perceived harm and & & (i.e., the study was a literature review) \\
& $\begin{array}{l}\text { addictiveness of e-cigarette } \\
\text { 4. Sample were previous or current users } \\
\text { of e-cigarette in nation/s of study } \\
\text { population }\end{array}$ \\
5. Available in full-text &
\end{tabular}

former cigarette smokers, that they use ecigarette to reduce or eliminate cigarette consumption and perceived e-cigarette as less harmful than cigarettes. Even though there is evidence that e-cigarette are effective in reducing or eliminating cigarette consumption, this finding is not consistent ${ }^{13,14}$. The role of perceptions and beliefs in behavior adoption is critical to understanding modes of intervention and cessation ${ }^{15}$. As e-cigarette continue to rise in popularity, it is important to explore how e-cigarette users on perceptions of harm and addiction risk of e-cigarette smoking.

The aim of this study is to review and determine perceived harm and addictiveness of e-cigarette among e-cigarette users in the general population worldwide using data obtained from systematic review. This study may provide insights lead to the design of more effective campaigns that communicate potential harms and addictiveness of ecigarette by analyzing e-cigarette users' perceptions regarding e-cigarette smoking.

\section{METHODS}

This research is a systematic review to find out the perceived harm and addictiveness of e-cigarette among e-cigarette users from several related studies. There were 3 main steps to gain the data; first we identify and select related research about our topic. Second, we assess the retrieved research that met all eligibility criteria. Then third, we made the review and data extraction for each study.

\section{Study identification}

Relevant research studies were located through an extensive search from three electronic databases (PubMed, Science Direct, and Cochrane Database of Systematic Reviews) and Google Scholar on October 2018. We conducted a systematic literature search for published articles in English that reported about perceived harm and addictiveness of ecigarette among e-cigarette users prior to recent years (2008 - 2018).

Preliminary hand search of the literature was completed in order to identify appropriate keywords. Key terms used for the search were as follows: "perceived harm", "perceived risk", "harm and addictiveness", "belief", "electronic cigarette", "e-cigarette", "vaping". Search terms were combined using the operators "AND" and "OR" to ensure that all relevant articles were located. Only articles that had explicitly defined measures those variables of interest were included, with inclusion and exclusion criteria shown in Table I.

\section{Study quality assessment}

About 88 studies were initially collected and reviewed: 84 from the initial search strategy and an additional 4 articles were collected from tracking of the literature. After further tracking of references from the retrieved studies only 5 studies were finally analyzed that met all eligibility criteria. Metaanalytic techniques could not be adequately performed because of the limited included 


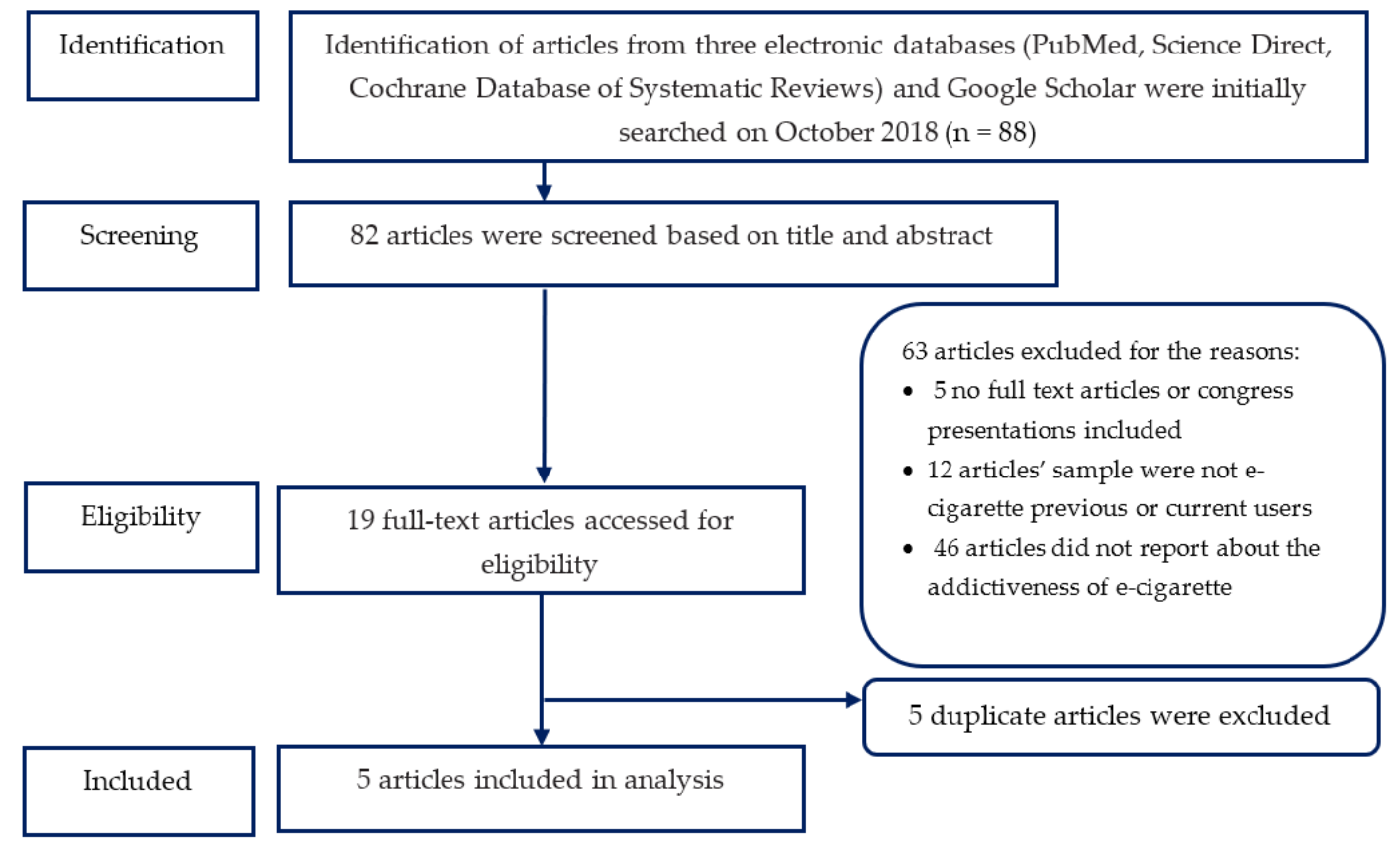

Figure 1. PRISMA Diagram of Retrieved Studies

and heterogeneity in the method and design across studies. However, to facilitate our analysis and discussion, we have grouped the results of the review to examine the comparison of perceived harm and addictiveness of e-cigarette and conventional cigarette also perceptions between e-cigarette users and non users. The PRISMA diagram of retrieved studies (Figure 1).

\section{Data extraction}

Data were independently extracted by two independent researchers. Data extraction form included details of study design, research sample, countries, and selection of variables, approach, objectives and the result of each study. Non-agreement or any dissimilarity on the data extraction was resolved by discussion among the authors.

\section{RESULTS AND DISCUSSION Details of selected studies}

The retrieved studies consisted of varied number of population and conducted from different countries (US, Texas, North Carolina, and Minnesota). They were published from different kind of publication sites. We also found a variety of years of publication within the study, with all study were conducted in recent 5 years (2014 - 2018).

The selected studies consisted of three cross-sectional studies, one longitudinal study and one prospective study. Variation of the respondents of study sample came from wide range of ages and population, start from adolescents aged $14-18$ years, undergraduate students, young adults and adults aged $18-87$ years. Most of studies using approach by direct and indirect self-administered questionnaire and interview either by direct or indirect media to the respondents. The methodological characteristics for selected studies of this paper (Table II).

\section{Perceived harm and addictiveness of e- cigarette}

The data extraction about study objectives, perceived harm, addictiveness and predictors of e-cigarette use of five selected studies in this systematic review can be seen in Table III. Information of the participants or study's sample was assessed mostly by selfreported questionnaire with specific kind of question related to perceived harm 
Table II. Methodology of Selected Studies

\begin{tabular}{|c|c|c|c|c|c|}
\hline Study & Country & Respondents & $\begin{array}{c}\text { Sample } \\
\text { size }\end{array}$ & Method & Data analysis tools \\
\hline $\begin{array}{l}\text { Reinhold } \\
\text { et al., } \\
2017^{16}\end{array}$ & US & $\begin{array}{l}\text { Students at Midwestern } \\
\text { university between the } \\
\text { ages of } 18-24\end{array}$ & 6,037 & $\begin{array}{l}\text { Cross- } \\
\text { sectiona } \\
\text { l study }\end{array}$ & SAS version 9.3 \\
\hline $\begin{array}{l}\text { Cooper et } \\
\text { al., } 2016^{19}\end{array}$ & Texas & $\begin{array}{l}\text { 6th, } 8 \text { th and } 10 \text { th grade } \\
\text { students' tobacco use } \\
\text { behaviors }\end{array}$ & 3,704 & $\begin{array}{l}\text { Cross- } \\
\text { sectiona } \\
\text { 1 study }\end{array}$ & $\begin{array}{l}\text { Stata } 14.1 \text { College } \\
\text { Station, TX }\end{array}$ \\
\hline $\begin{array}{l}\text { Tan et al., } \\
2016^{17}\end{array}$ & US & Adults aged $18-87$ years & 527 & $\begin{array}{l}\text { Longitu } \\
\text { dinal } \\
\text { study }\end{array}$ & Stata 13 SVY \\
\hline $\begin{array}{l}\text { Rohde et } \\
\text { al., } 2018^{12}\end{array}$ & $\begin{array}{l}\text { North } \\
\text { Carolina }\end{array}$ & $\begin{array}{l}\text { Adolescents aged } 14-18 \\
\text { who were susceptible to } \\
\text { or had used any tobacco } \\
\text { product }\end{array}$ & 69 & $\begin{array}{l}\text { Cross- } \\
\text { sectiona } \\
\text { l study }\end{array}$ & SPSS version 23 \\
\hline $\begin{array}{l}\text { Choi and } \\
\text { Foster, } \\
2014^{18}\end{array}$ & $\begin{array}{l}\text { Minneso } \\
\text { ta }\end{array}$ & $\begin{array}{l}\text { Young adults (mean age } \\
=24.1 \text { years) from the } \\
\text { Minnesota Adolescent } \\
\text { Community Cohort }\end{array}$ & 1,379 & $\begin{array}{l}\text { Prospect } \\
\text { ive } \\
\text { study }\end{array}$ & PC-SAS version 9.2 \\
\hline
\end{tabular}

studies and addictiveness of e-cigarette among the users. Two out of five studies were used to determining perceptions between of e-cigarette and conventional cigarette among e-cigarette users. Meanwhile three other studies were determined the difference of perceived harm and addictiveness of ecigarette between e-cigarette users and non users.

In Reinhold et al., (2017) study, flavored e-cigarette perceived less harmful than tobacco cigarettes among e-cigarette users with average perceived harm value $4.49 \pm 2.12$ and $6.15 \pm 1.70$, respectively ${ }^{16}$. Meanwhile beliefs about benefits (vaping is less harmful than smoking and vaping can help people quit smoking completely), $\mathrm{RR}=2.6$ and 4.9 respectively, $\mathrm{p}<0.05)$, ever users were more likely to agree than never users from Tan et al., (2016) study ${ }^{17}$. Choi and Foster (2014) also reported that perceptions of e-cigarette users that agreed about e-cigarette are less harmful than cigarettes had adjusted OR: 2.34
$(1.49-3.69)^{18}$. E-cigarette users had higher odds $(\mathrm{OR}=4.77,95 \% \mathrm{CI}: 3.19-7.15)$ of reporting that e-cigarette were "not at all" harmful to health compared to non e-cigarette users from Cooper et al., (2016) study ${ }^{19}$. Compared to never-users, e-cigarette everusers were significantly less likely to worry about the health risks of e-cigarette ${ }^{12}$.

Furthermore about perceived addictiveness, tobacco cigarettes were perceived as much more addictive than ecigarette among e-cigarette users ${ }^{16}$. Choi and Foster (2014) study also stated that respondents agreed about e-cigarette are less addictive than cigarettes (OR: 1.16, 0.73 $1.85)^{18}$. Perception of former e-cigarette users on addiction was lower than non users if using vape or e-cigarette everyday (RR 0.2 vs $1.0, \mathrm{p}<$ $\left.0.01^{17}\right)$. Cooper et al., (2016) study stated ecigarette users had higher odds $(\mathrm{OR}=1.72$; $95 \%$ CI: $1.12-2.65$ ) of reporting that e-cigarette were "not at all" addictive compared to non users $^{19}$. Compared to never-users, e-cigarette 
Table IIIa. Perceived Harm and Addictiveness of E-Cigarette

\begin{tabular}{|c|c|c|c|c|}
\hline Study & Objectives & $\begin{array}{l}\text { Perceived } \\
\text { harm }\end{array}$ & $\begin{array}{c}\text { Perceived } \\
\text { addictiveness }\end{array}$ & $\begin{array}{c}\text { Predictors of } \\
\text { perceived harm and } \\
\text { addictiveness }\end{array}$ \\
\hline $\begin{array}{l}\text { Reinhold et } \\
\text { al., 201716 }\end{array}$ & $\begin{array}{l}\text { To investigate if } \\
\text { advertising } \\
\text { exposure was } \\
\text { related to } \\
\text { perceptions of } \\
\text { harm, } \\
\text { addictiveness, } \\
\text { and acceptability } \\
\text { of use of e- } \\
\text { cigarette in } \\
\text { places where } \\
\text { traditional } \\
\text { cigarettes are } \\
\text { banned }\end{array}$ & $\begin{array}{l}\text { Flavored e- } \\
\text { cigarette }(4.49 \pm \\
2.12) \text { is less } \\
\text { harmful than } \\
\text { tobacco } \\
\text { cigarettes }(6.15 \\
\pm 1.70)\end{array}$ & $\begin{array}{l}\text { Flavored e- } \\
\text { cigarette }(5.61 \pm \\
2.17) \text { is less } \\
\text { addictive than } \\
\text { tobacco } \\
\text { cigarettes }(6.93 \pm \\
1.58)\end{array}$ & $\begin{array}{l}\text { Being male, ever } \\
\text { having used an e- } \\
\text { cigarette, ever having } \\
\text { been a smoker, } \\
\text { having a mother who } \\
\text { smoked, and having } \\
\text { seen an } \\
\text { advertisement on the } \\
\text { internet remained } \\
\text { associated with lower } \\
\text { perceived harm of e- } \\
\text { cigarette use. Only } \\
\text { being male and } \\
\text { lifetime e-cigarette } \\
\text { use were associated } \\
\text { with significantly } \\
\text { lower perceived } \\
\text { addictiveness of e- } \\
\text { cigarette }\end{array}$ \\
\hline $\begin{array}{l}\text { Cooper et } \\
\text { al., } 2016^{19}\end{array}$ & $\begin{array}{l}\text { To understand } \\
\text { how e-cigarette } \\
\text { are perceived } \\
\text { and how these } \\
\text { perceptions are } \\
\text { associated with } \\
\text { their decision } \\
\text { whether or not } \\
\text { to use them }\end{array}$ & $\begin{array}{l}\text { E-cigarette } \\
\text { users had } \\
\text { higher odds } \\
(\mathrm{OR}=4.77,95 \% \\
\text { CI: } 3.19-7.15) \\
\text { of reporting } \\
\text { that e-cigarette } \\
\text { were "not at } \\
\text { all" harmful to } \\
\text { health } \\
\text { compared to } \\
\text { non e-cigarette } \\
\text { users }\end{array}$ & $\begin{array}{l}\text { E-cigarette users } \\
\text { had higher odds } \\
(\mathrm{OR}=1.72 ; 95 \% \\
\text { CI: } 1.12-2.65) \\
\text { of reporting that } \\
\text { e-cigarette were } \\
\text { "not at all" } \\
\text { addictive } \\
\text { compared to } \\
\text { non users }\end{array}$ & $\begin{array}{l}\text { None of predictors } \\
\text { was statistically } \\
\text { significant; therefore, } \\
\text { all the models } \\
\text { without interactions } \\
\text { were used }\end{array}$ \\
\hline $\begin{array}{l}\text { Tan et al., } \\
2016^{17}\end{array}$ & $\begin{array}{l}\text { To assess public } \\
\text { beliefs about e- } \\
\text { cigarette' } \\
\text { potential harms } \\
\text { and benefits }\end{array}$ & $\begin{array}{l}\text { Beliefs about } \\
\text { benefits } \\
\text { (vaping is less } \\
\text { harmful than } \\
\text { smoking), ever } \\
\text { users were } \\
\text { more likely to } \\
\text { agree (RR = 2.6, } \\
\mathrm{p}<0.05 \text { ) than } \\
\text { never users }\end{array}$ & $\begin{array}{l}\text { Perception of } \\
\text { ever users on } \\
\text { addiction if } \\
\text { using vape or e- } \\
\text { cigarette } \\
\text { everyday is } \\
\text { lower than non } \\
\text { e-cigarette users } \\
\text { (RR } 0.2 \text { vs } 1.0 \text {, p } \\
<0.01 \text { ) }\end{array}$ & $\begin{array}{l}\text { Significant correlates } \\
\text { for various belief } \\
\text { items were age, race, } \\
\text { education, and health } \\
\text { status }\end{array}$ \\
\hline
\end{tabular}


Table IIIb. Perceived harm and addictiveness of e-cigarette

\begin{tabular}{|c|c|c|c|c|}
\hline Study & Objectives & $\begin{array}{l}\text { Perceived } \\
\text { harm }\end{array}$ & $\begin{array}{c}\text { Perceived } \\
\text { addictiveness }\end{array}$ & $\begin{array}{c}\text { Predictors of } \\
\text { perceived harm and } \\
\text { addictiveness }\end{array}$ \\
\hline $\begin{array}{l}\text { Rohde et al., } \\
2018^{12}\end{array}$ & $\begin{array}{l}\text { To examined } \\
\text { adolescents' } \\
\text { knowledge and } \\
\text { beliefs about e- } \\
\text { cigarette risks }\end{array}$ & $\begin{array}{l}\text { Compared to } \\
\text { never-users, e- } \\
\text { cigarette ever- } \\
\text { users were } \\
\text { significantly } \\
\text { less likely to } \\
\text { worry about } \\
\text { the health risks } \\
\text { of e-cigarette } \\
(\mathrm{M}=3.18 \text { vs. } \mathrm{M} \\
=3.80, \mathrm{p}= \\
0.031)\end{array}$ & $\begin{array}{l}\text { Compared to } \\
\text { never-users, e- } \\
\text { cigarette ever- } \\
\text { users less likely } \\
\text { to believe that e- } \\
\text { cigarette use } \\
\text { would lead to } \\
\text { addiction }(\mathrm{M}= \\
2.12 \text { vs. } \mathrm{M}=3.10 \text {, } \\
\mathrm{p}<0.001)\end{array}$ & $\begin{array}{l}\text { Prior combustible } \\
\text { cigarette use, } \\
\text { mother's education, } \\
\text { and addiction risk } \\
\text { beliefs about e- } \\
\text { cigarette emerged as } \\
\text { significant predictors } \\
\text { of adolescents' e- } \\
\text { cigarette use. This } \\
\text { study reveals that } \\
\text { knowledge is not } \\
\text { associated with } \\
\text { adolescent e-cigarette } \\
\text { use, risk beliefs do } \\
\text { predict use }\end{array}$ \\
\hline $\begin{array}{l}\text { Choi and } \\
\text { Foster, } \\
2014^{18}\end{array}$ & $\begin{array}{l}\text { To identify the } \\
\text { beliefs } \\
\text { predicting } \\
\text { subsequent use } \\
\text { of e-cigarette }\end{array}$ & $\begin{array}{l}\text { Agreed that e- } \\
\text { cigarette are } \\
\text { less harmful } \\
\text { than cigarettes } \\
(\text { aOR }: 2.34 \\
(1.49-3.69))\end{array}$ & $\begin{array}{l}\text { Agreed that e- } \\
\text { cigarette are less } \\
\text { addictive than } \\
\text { cigarettes (OR : } \\
1.16(0.73-1.85)\end{array}$ & $\begin{array}{l}\text { Given that young } \\
\text { adults are still } \\
\text { developing their } \\
\text { tobacco use } \\
\text { behaviors, informing } \\
\text { them about the lack of } \\
\text { evidence to support e- } \\
\text { cigarette as quit aids } \\
\text { and the unknown } \\
\text { health risk of e- } \\
\text { cigarette may deter } \\
\text { young adults from } \\
\text { trying these products }\end{array}$ \\
\hline
\end{tabular}

$\mathrm{RR}$ : relative risk; aOR adjust odds ratio; $\mathrm{M}$ : mean

ever-users less likely to believe that e-cigarette use would lead to addiction (Mean 2.12 vs 3.10, $\mathrm{p}<0.001)^{12}$.

There were some predictors associated with perceived harm and addictiveness of ecigarette from the selected studies. Being male, ever having used an e-cigarette, ever having been a smoker, having a mother who smoked, and having seen an advertisement on the internet remained associated with lower perceived harm of e-cigarette use. Only being male and lifetime e-cigarette uses were associated with significantly lower perceived addictiveness of e-cigarette ${ }^{16}$. Age, race, education, and health status also had been significant correlates for various belief items of e-cigarette users ${ }^{17}$. Prior combustible cigarette use, mother's education, and addiction risk beliefs about e-cigarette emerged as significant predictors of adolescents' e-cigarette use from Rohde et al., 2018 study $^{12}$. Given that young adults are still developing their tobacco use behaviors, informing them about the lack of evidence to support e-cigarette as quit aids 
and the unknown health risk of e-cigarette may deter young adults from trying these products $^{18}$.

E-cigarette represent a new way to administer substances to the respiratory tract $^{20}$, using battery power to heat an element and disperse a solution that usually contains nicotine. The dispersion of the solution leads to the create an aerosol that can be inhaled by the user $^{21}$. The main differences between ecigarette and tobacco cigarettes are expectation to largely determine potential risk discrepancies of the combustion. Other than nicotine, the ingredients of e-cigarette liquids are compounds that have been used extensively in food, pharmaceutical and cosmetic products. There is limited evidence from clinical studies about the effects of inhaling those compounds ${ }^{22}$.

The safety and risk profile of e-cigarette is particularly important, because e-cigarette have been on the market for few years and the long-term population health effects are unknown ${ }^{23}$. Based on our review, most ecigarette users from the selected study stated that e-cigarette was perceived less harm than tobacco cigarettes. The study highlights the need to design public health messages that accurately interpret the scientific data on the potential harm of e-cigarette and clearly differentiate the absolute from the relative harm of e-cigarette ${ }^{24}$.

Our review also found that most respondents state that e-cigarette was perceived less addictive than tobacco cigarettes among e-cigarette users. Long-term nicotine addiction is a concern for many health professionals and some smokers themselves ${ }^{25}$. In 2016, FDA announced its final rule to regulate e-cigarette under the "Family Smoking Prevention and Tobacco Control Act", which outlines options for the regulation of e-cigarette, particularly as they relate to youth and young adults, based on successful smoking policies ${ }^{26}$. Whilst it is acknowledged that more research is needed into the constituents and long-term effects of ecigarette, because public deserve an accurate and evidence based in order to inform their choice $^{27}$, especially for youth and young adults.

There were some predictors associated with perceived harm and addictiveness of ecigarette based on our review, including sex, age, race, education, and health belief for smoking cessation. Psychosocial factors like home use of each product, friends' use, positive attitudes toward e-cigarette and participant perception of the harm of ecigarette were have strongly positive association both with e-cigarette and cigarette $u^{2}{ }^{28}$. Another study state that college students perceive e-cigarette as less addictive than tobacco cigarette is concerning because among adolescents, intention to use cigarette has been found to be highly correlated with perceived addictiveness ${ }^{29}$. Initial hopes that e-cigarette would be both a less toxic competitor to cigarette and help people to quit smoking have not translated into real-world positive effects. Instead, e-cigarette have simply become another class of tobacco products that are maintaining and expanding the tobacco epidemic ${ }^{21}$.

Potential limitations need to be addressed in interpreting the findings of this review, including heterogeneity of the studies' method made it challenging in summarizing the review. Based on our findings, study about perceived harm and addictiveness of ecigarette was still limited, especially study from developing countries which also may the factor of this review cannot generally represent the issue in that region. Therefore, we are suggesting more e-cigarette harm and addictiveness study will conduct with an accurate and particular method in the near future. Further research should address the scientific uncertainty surrounding the use ecigarette $^{30,31}$ and consider means to clearly convey information about its harm and addiction risk.

\section{CONCLUSION}

Our review conclude that e-cigarette were perceived less harm and less addictive than tobacco cigarettes among e-cigarette users than non users. There were many 
predictors associated with perceived harm and addictiveness of e-cigarette, including sex, age, race, education, advertisement and health belief for smoking cessation. Further study about the safety and risk profile of e-cigarette is particularly important to design public health messages that accurately interpret the scientific data on the potential harm and addictiveness of e-cigarette.

\section{ACKNOWLEDGMENT}

The authors would like to acknowledge all the research team for their contribution in this review and Universitas Gadjah Mada for providing the funding of manuscript preparation.

\section{DAFTAR PUSTAKA}

1. Wang MP., Li WHC., Jiang N., Chu LY., Kwong A., Lai V., et al., E-Cigarette awareness, perceptions and use among community-recruited smokers in Hong Kong. PLoS ONE. 2015;10(10).

2. Farsalinos K. E-cigarettes: an aid in smoking cessation, or a new health hazard? Ther Adv Respir Dis. 2018;12:1 -20 .

3. Owotomo O., Maslowsky J., Loukas A. Perceptions of the harm and addictiveness of conventional cigarette smoking among adolescent e-cigarette users. I Adolescent Health. 2018;62:87-93.

4. Giovacchini CX., Pacek L., McClernon F.J, Que LG. Use and perceived risk of electronic cigarettes among North Carolina middle and high school students. $N$ North Caroline Med J. 2017;78(1):7-13.

5. Rodriguez E., Parrón T., Alarcón R. Perceptions and use of the e-cigarette among University Students. Arch Bronconeumol. 2017;53(11):641-52.

6. Abo-Elkheir OI., Sobh E. Knowledge about electronic cigarettes and its perception: a community survey, Egypt Respiratory Res. 2016;17:58.

7. Tan ASL., Bigman CA. E-cigarette awareness and perceived harmfulness: prevalence and associations with smoking cessation outcomes. Am J Prev Med. 2014;47(2):141-9.

8. Cheung YTD., Wang MP., Ho SY., Jiang N., Kwong A., Lai V., et al., Public support for electronic cigarette regulation in Hong Kong: A populationbased cross-sectional study. Int $J$ Environ Res Pub Health. 2017;14:709.

9. Cummings KM., Dresler CM., Field JK., Fox J., Gritz ER., Hanna NH., et al., Ecigarettes and cancer patients. J Thoracic Oncology. 2014;9(4).

10. Karbouji MA., Abduldaem AM., Allogmani AM., Alharbi AS., Alnozha O., Al-Zalabani AH. Awareness and attitude toward smoking e-cigarettes (Vape) among smokers in Saudi Arabia 2017. Egypt J Hospital Med. 2018;70(8):1346-51.

11. Maglalang DD., Brown-Johnson C., Prochaska JJ. Associations with ecigarette use among Asian American and Pacific Islander young adults in California. Prev Med Reports. 2016;4:2932.

12. Rohde JA., Noar SM., Horvitz C., Lazard AJ., Ross JC., Sutfin EL. The role of knowledge and risk beliefs in adolescent e-cigarette use: A pilot study. Int J Environ Res Pub Health. 2018;15:830.

13. Volesky KD., Mak AI., Scherf C., Watson LM., Cassol E. Characteristics of e-cigarette users and their perceptions of the benefits, harms and risks of ecigarette use: survey results from a convenience sample in Ottawa, Canada. Policy Pract. 2016;36(7).

14. Pisinger C. A systematic review of health effects of electronic cigarettes. Denmark: Research Centre for Prevention and Health. 2015. Geneva: WHO.

15. Hall MT., Austin R., Do TA., AG R. Perceptions of harm from electroniccigarette use among a sample of US Navy personnel. Tob Prev Cessation. 2017;3:128. 
16. Reinhold B., Fischbein R., Bhamidipalli SS., Bryant J., Kenne DR. Associations of attitudes towards electronic cigarettes with advertisement exposure and social determinants: a cross sectional study. Tob Induced Diseases. 2017;15(13).

17. Tan ASL., Lee C., Bigman CA. Comparison of beliefs about ecigarettes' harms and benefits among never users and ever users of ecigarettes. Drug Alcohol Dependence. 2016;158:67-75.

18. Choi K., JL F. Beliefs and Experimentation with Electronic Cigarettes: A prospective anaysis among young adults. Am J Prev Med. 2014 46(2):175-8.

19. Cooper M., Harrell MB., Pérez A., Delk J., Perry CL. Flavorings and perceived harm and addictiveness of e-cigarettes among youth. Tob Regul Sci. 2016;2(3):278-89.

20. Etter., Jean-François., Bullen., Chris. Electronic cigarette: users profile, utilization, satisfaction and perceived efficacy. Addiction. 2011;106(11): 201728.

21. Hitchman SC., Brose LS., Brown J., Robson D., McNeill A. Associations between e-cigarette type, frequency of use, and quitting smoking: Findings from a longitudinal online panel survey in Great Britain. Nicotine Tob Res. 2015:1187-94.

22. Farsalinos KE., Romagna G., Tsiapras D., Kyrzopoulos S., Voudris V. Characteristics., perceived side effects and benefits of electronic cigarette use: A worldwide survey of more than 19,000 consumers. Int J Environ Res Pub Health. 2014;11:4356-73.

23. Glantz SA., Bareham DW. Annual review of public health e-cigarettes: Use, effects on smoking, risks, and policy implications. Annu Rev Pub Health. 2018;39(28):1-28.

24. Wackowski OA., Hammond D., O'Connor RJ., Strasser AA., Delnevo $\mathrm{CD}$. Considerations and future research directions for e-cigarette warningsFindings from expert interviews. Int J Environ Res Pub Health. 2017;14:781.

25. Cox S., Jakes S. Nicotine and ecigarettes: Rethinking addiction in the context of reduced harm. Int J Drug Policy. 2017;44:84-5.

26. U.S. Department of Health and Human Services. E-Cigarette Use Among Youth and Young Adults. 2016. New York: USDHHS.

27. Levy DT., Borland R., Lindblom EN., Goniewicz ML., Meza R., Holford TR, et al., Potential deaths averted in USA by replacing cigarettes with e-cigarettes. Tob Control. 2017;27(1):18-25.

28. Trimis CLB., Berhane K., Unger JB., Cruz TB., Huh J., Leventhal AM., et al., Psychosocial factors associated with adolescent electronic cigarette and cigarette use. Pediatrics. 2015;136(2).

29. East K., Brose LS., McNeill A., Cheeseman H., Arnott D., Hitchman SC. Harm perceptions of electronic cigarettes and nicotine: A nationally representative cross-sectional survey of young people in Great Britain. Drug Alcohol Depend. 2018;1(192):257-263.

30. Hart JL., Walker KL., Sears CG., Lee AS., Ridner SL.., Keith RJ. E-cigarette use and perceived health change: Better health through vaping? Tob Induc Diseases. 2018;16:48.

31. Hartwell G., Thomas S., Egan M., Gilmore A., Petticrew M. E-cigarettes and equity: a systematic review of differences in awareness and use between sociodemographic groups. Tob Control. 2016;0:1-7. 